\title{
INFLUENCE OF TECTONIC FAULTS ON THE CONDITIONS AND PROPERTIES OF SOME COMPONENTS OF A BIOGEOCENOSIS IN A SUBARCTIC AREA
}

\author{
VLADIMIR BELYAEV ${ }^{1}$, KONSTANTIN BOGOLYTSYN ${ }^{1,2}$, \\ OLGA BROVKO ${ }^{1}$, YURIY KUTINOV ${ }^{1}$, NIKOLAY NEVEROV ${ }^{1}$, \\ IRINA PALAMARCHUK ${ }^{1}$, TATIANA BOYTSOVA ${ }^{1}$, DMITRIY \\ CHUKHCHIN $^{2}$, DMITRIY ZHILTSOV ${ }^{1}$, and NATALIA GORSHKOVA ${ }^{1, *}$
}

${ }^{1}$ N. Laverov Federal Center for Integrated Arctic Research, Northern Dvina Embankment 23, Arkhangelsk 163000, Russia

${ }^{2}$ Northern Federal University named after M. V. Lomonosov, Northern Dvina Embankment 17, Arkhangelsk 163000, Russia

*Corresponding author: valchuk.natalia@mail.ru

\section{ABSTRACT}

In geoecology, the nature of the effect of tectonic faults on the environment is not well studied. The influence of natural landscapegeochemical factors on the state and properties of some components of biota of different hierarchical levels is studied at the intersection of two tectonic faults (Velsko-Ust'yanskiy tectonic knot (TK)) in the Arkhangelsk region. Two species of shrubby lichens (Cladonia stellaris Opiz. and Usnea subfloridana Stirt.) and woody plants (spruce - Picea abies L. and Scots pine - Pinus sylvestris L.) were chosen as test systems. The field studies were carried out at nine test sites (in the centre, on the periphery and some distance from TK - the background reference point) in different types of forest. The ash content of samples of the lichen Cladonia growing in the centre of the TK (1.12-1.22\%) is double that in the control area (0.56-0.58\%), and for the lichen Usnea, it is seven times higher (6.82-6.99\% at the centre and 0.97-1.09\% in the control area). The ash content of tree bark collected at the centre of TK (1.27-1.29\%) is double that at the control site (0.56-0.76\%). This indicates a significant accumulation of metals in the vegetation in the TK zone. The accumulation of heavy metals, the low water content of plants, the influence of geomagnetic fields and other factors provoke excessive generation of active oxygen radicals and plants have various physiological, biochemical and morpho-biometric means of combating their adverse effects. The synergism of the cooperative protective action of lichen matrix components on oxidative stress is expressed in terms of changes in biochemical parameters. At the centre of the TK, the lichens contains up to $190 \mu \mathrm{g} \mathrm{g}^{-1}$ of ascorbic acid, whereas in the control area it does not exceed $130 \mu \mathrm{g} \mathrm{g}^{-1}$. The content of usninic acid in the centre is 1.5-2 times higher for the Usnea subfloridana and is 1.5 times higher for Cladonia stellaris compared to the level in the control area.

Keywords: biochemical activity; lichens; pine; spruce; tectonic knot

\section{Introduction}

Natural geological processes, unlike technogenic processes, function continuously and result in a global migration of matter into the environment, which has a negative effect on biota. Modes and dynamics of interaction of the lithosphere, biosphere, atmosphere and ionosphere play a significant role in the development of the Earth's crust, primarily the tectonic faults. The features of the structure and properties of tectonic zones determine not only deep degassing and increased relaxation of rocks, but also the conditions for the formation of sources of electromagnetic signals and energy exchange between geophysical fields of different natures, including external and internal. Currently, there is a significant amount of data, indicating the presence of a strong relationship between the processes in the Earth's biosphere, heliogeophysical, meteorological and lithospheric factors, primarily for tectonic faults and their intersections, in convective heat flow. In tectonic fault zones, the geochemical, geophysical and geodynamic fields can jointly affect the biota.

The most interesting are the areas above where tectonic faults intersect (TKs). TKs are complex, three-dimensional bodies that extend to great depths. With the increase in the number of intersecting tectonic faults in an area the degree of fragmentation, permeability and depth of the Earth's crust increases and vertical highly perme- able areas develop that over long periods of time, result in an interaction between the crust and the mantle, and a constant flow of fluids and gas from deep within the crust (Kutinov et al. 2009; Kutinov and Chistova 2012) and an inflow of mineralised waters, which contributes to the concentration of a number of elements, including heavy metals. TKs, with a complex conduction field, can be sources of induced eddy currents that change the overall picture of the geomagnetic field (a kind of natural dipole).

The above indicates there are a number of environmental factors associated with tectonic nodes, which can have a joint effect on biological systems at different hierarchical levels. It is likely that such patterns are characterised by special patterns of accumulation, migration and physical and chemical transformation of pollutants (Caine et al. 1996; Evans et al. 1997; Caine and Forster 1999; Rawling et al. 2001; Bense et al. 2013).

Early studies show that the structure of vegetation growing over TKs in the subarctic is different. In these areas the soil is also polluted and there are high levels of heavy metals in the bark of trees, ionisation effects in the atmosphere and differences in the trees, snow cover, clouds and rainfall in summer (Gofarov et al. 2006; Kutinov et al. 2009; Kutinov and Chistova 2012). Thus, in these areas plants are exposed to many physical and chemical effects, which may act synergistically on the plants. 


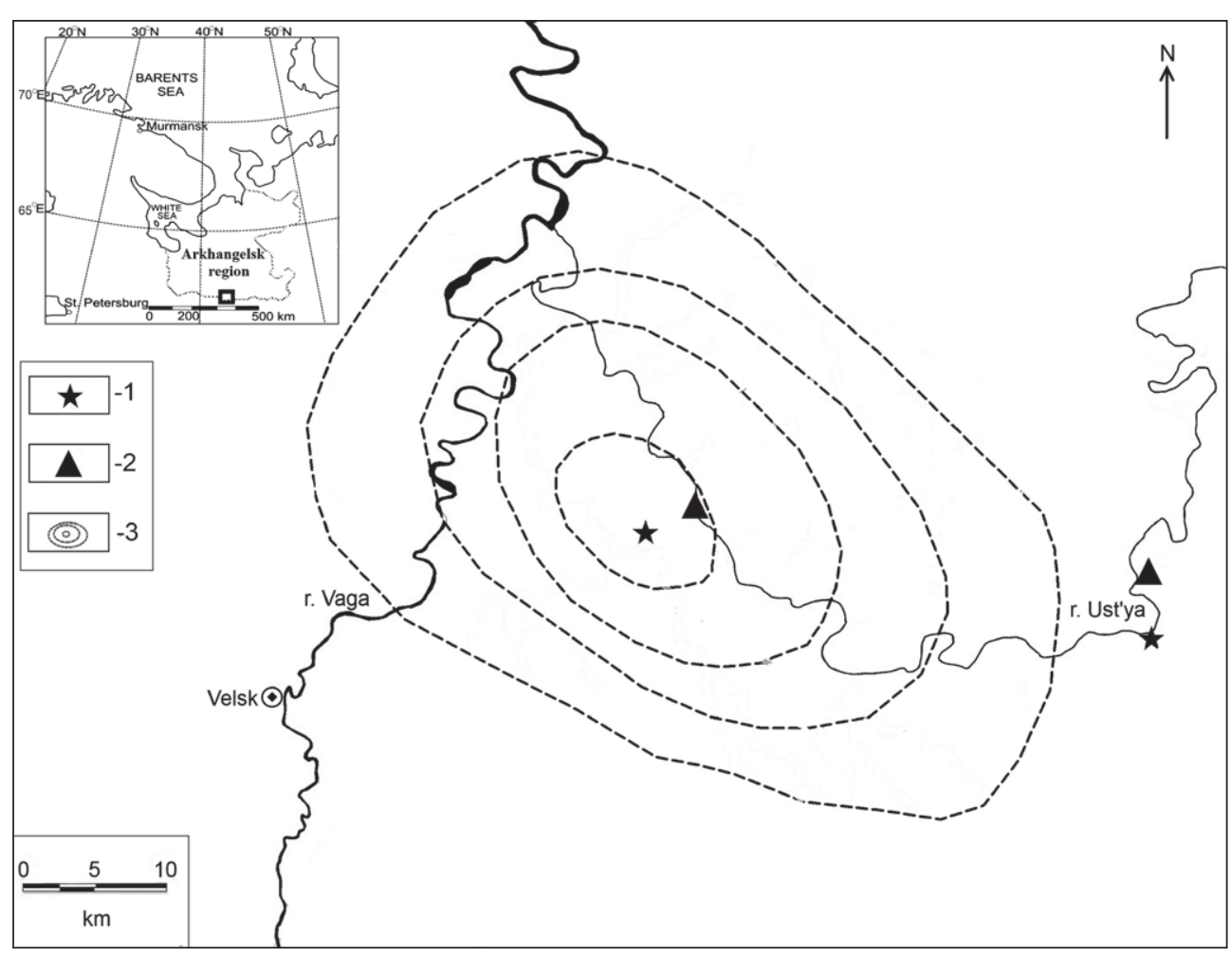

Fig. 1 Map showing the location of the sample plots (SP): 1 - in pine forests; 2 - in spruce forests; 3 - isolines of tectonic dislocation density. $1,3,5,7$ - SP in the center of KF; 9 - SP at the periphery of KF; 2, 4, 6, 8 - SP outside the TK zone (control).

The primary reaction of a plant cell to a negative effect is oxidative stress (Beschel 1957; Rydzak 1968; Magomedova 1996; Markovskaya 2010; Brovko et al. 2016). The most important response of plants to stress is a physiological and biochemical restructuring of their metabolic processes. It is known that there are changes in the activity of components of the antioxidant system (AOS) in response to adverse environmental factors such as drought (Zhang and Kirkham 1994), salinity (Meloni et al. 2003), low temperature (Aroca et al. 2001) and increasing concentrations of pollutants in the environment (Chapin 1991; Alscher et al. 1997; Prasad et al. 1999; Chirkova 2002; Polesskaya et al. 2004), etc. However, there are practically no studies on changes in AOS during the ontogenetic development of lichens growing when geological structures are violated (in the region of TKs?).

The goal of this study is to determine how woody plants and lichens have adapted to living in the region of a TK in subarctic conditions in North-West Russia.

\section{Material and Methods}

\section{Materials}

The plants used in this study were two species of shrubby lichens (Cladina stellaris Opiz. and Usnea subfloridana Stirt.) and two conifers (Spruce - Picea abies L., pine - Pinus sylvestris L.). Lichens were identified following Golubkova et al. (1978). The sample plots (SPs) were at permanent test sites established in 2014-2017 in the middle taiga subzone in the district Velsko-Ust'yanskiy TK in the Arkhangelsk region (Fig. 1).

The underlying rocks at the centre of the TK are sandstones, sands and siltstones of the middle Perm, and outside of the TK, variegated clays, sands and marls of the same age. The covering deposits are upper quaternary sands of lake-glacial and alluvial origin. The soils in the centre of the TK are podzolic and illuvial-ferruginous on quartz sands, outside the TK, they are podsolic on a loamy noncarbonate moraine (Atlas of the Arkhangelsk region 1976).

In total, there were nine test areas (Fig. 1, Table 1): four in the centre of the Velsko-Ust'yanskiy TK (SP-C) and four outside (SP-CL), two in a cowberry pine forest, a lichen pine forest, a bilberry, pine and spruce forest in the centre of the TK and in the control area and SP 9 - on the periphery. SPs were selected to be as similar as possible in terms of forest characteristics. The characteristics of forest stands are presented in Table 1.

Table 1 shows that the trees in the SPs have very similar characteristics and differ only in their location relative to the TK (centre and outside the node - control).

In addition, in order to determine the age of the trees 30 cores samples were collected using a core sampler from trees at a height of $1.3 \mathrm{~m}$ at each sample plot located in the centre of the TK and in the control area. The age of the forest and any damage to the wood was determined using Lintab 6 and TSAP-Win (version 4.80) (Rinn 2007). 
Table 1 Key characteristics: values (means) of the sampled forests.

\begin{tabular}{|c|c|c|c|c|c|c|}
\hline \multicolumn{2}{|l|}{ Sample plot } & \multirow{2}{*}{$\begin{array}{c}\text { Height (m) } \\
17\end{array}$} & \multirow{2}{*}{$\begin{array}{c}\text { Normality } \\
0.8\end{array}$} & \multirow{2}{*}{$\begin{array}{c}\begin{array}{c}\text { Stand } \\
\text { composition }\end{array} \\
7 \mathrm{P}: 3 \mathrm{~F}: \mathrm{B}\end{array}$} & \multirow{2}{*}{$\frac{\text { Age (yr) }}{65}$} & \multirow{2}{*}{ 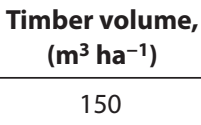 } \\
\hline & SP1-C & & & & & \\
\hline 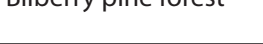 & $\mathrm{SP} 2-\mathrm{CL}$ & 19 & 0.7 & $8 \mathrm{P}: 2 \mathrm{~F}$ & 80 & 180 \\
\hline \multirow{2}{*}{ Lichen pine forest } & SP3-C & 12 & 0.6 & $10 \mathrm{P}$ & 90 & 40 \\
\hline & SP4-CL & 10 & 0.4 & $10 \mathrm{P}$ & 100 & 40 \\
\hline \multirow{2}{*}{ Cowberry pine forest } & SP5-C & 18 & 0.7 & $8 \mathrm{P}: 2 \mathrm{~B}$ & 80 & 220 \\
\hline & SP6-CL & 18 & 0.7 & $8 \mathrm{P}: 2 \mathrm{~B}$ & 70 & 210 \\
\hline \multirow{2}{*}{ Bilberry spruce forest } & SP7-C & 19 & 0.7 & $8 \mathrm{~F}: 2 \mathrm{~B}: \mathrm{L}$ & 70 & 250 \\
\hline & SP8-CL & 18 & 0.7 & 7F:1P:2B & 80 & 240 \\
\hline
\end{tabular}

Note: F - fir-tree, L - larch-tree, B - birch-tree, P - pine-tree

\section{Scanning electron microscopy}

The morphology of the samples was investigated using a ZEISS Sigma VP SEM scanning electron microscope (accelerating voltage, $10 \mathrm{kV}$; detector, InLens). A gold-palladium coating (80:20) no more than $5 \mathrm{~nm}$ thick was used. It was obtained using a QUORUM Q150T ES magnetron sputterer.

\section{The biochemical parameters}

The biochemical parameters of the two species of lichens that dominate the area studied but differ in their distribution were analysed. Of the soil growing (epigeous) and epiphytic lichens, Cladonia stellaris and Usnea subfloridana, respectively, were studied. The material was collected in the vegetative period (spring-autumn) from the three SPs (in the centre, at the periphery, outside the $\mathrm{TK}$, which acted as the control) in pine-bilberry forests of similar composition. Two SPs measuring $30 \times 30 \mathrm{~m}$ were established in each TK zone (centre, periphery) at a distance of $200 \mathrm{~m}$ from each other; at the centre (SP5-C) and the periphery of the TK (15 km from the centre - SP9), and outside the TK (50 km from the centre, the control SP6-C) (Fig. 1). Five to ten samples of both species of lichen were collected from each SP. A total of 160 samples of lichen were analysed. The composition of the vegetation in pine-bilberry forests is presented in Table 2.

\section{Analysis}

The water content in the samples was determined gravimetrically, the content of mineral substances was determined gravimetrically after dry ashing $\left(500^{\circ} \mathrm{C}\right)$. Elemental analysis of the lichens was done using an Euro EA-3000 element analyser (configuration [CNHS]) (EuroVector, Italy). The content of heavy metals and biogenic elements was determined using a XRF-1800 series waveguide X-ray fluorescence spectrometer (Shimadzu, Japan).

\section{Estimation of acids}

The content of ascorbic acid (AA) in lichens was determined spectrally using a UV-1800 spectrophotometer (Shimadzu, Japan) and 2.6-dichlorophenolindophenol
(Tilmans paint) according to (Voskresenskaya 2006). Optical density was measured at $515 \mathrm{~nm}$. The change in the staining intensity of the control and test sample is proportional to the amount of AA in the plant extract.

Usnic acid (UA) was extracted using acetone and quantified using a LCMS-2020 liquid quadrupole LCMmass spectrometer (Shimadzu, Japan) according to (Brovko et al. 2017). Chromatography conditions were: mobile phase $-0.5 \%$ aqueous solution of formic acid and acetonitrile in a volume ratio of 30:70; column Restek Ultra C18 $100 \mathrm{~mm}$ (length) $\times 3 \mathrm{~mm}$ (diameter), fixed phase grain size $3 \mu \mathrm{m}$, mobile phase flow rate $0.5 \mathrm{ml} \mathrm{min}^{-1}$, sample introduction volume $5 \mu \mathrm{l}$. Using a standard Sigma-Aldrich UA sample, calibration curves of the peak area versus the concentration in the range from $1 \mu \mathrm{g} \mathrm{l^{-1 }}$ to $0.1 \mathrm{mg} \mathrm{l}^{-1}$ were constructed. The calibration curves

Table 2 Composition of the vegetation in pine-bilberry forests in the district Velsky-Ust'yanskiy TK in the Arkhangelsk Region.

\begin{tabular}{|l|l|l|}
\hline \multicolumn{3}{|l|}{ Location of the trial plot in relation to KF } \\
\hline SP 6-C (control) & SP 9 & SP 5-C (center) \\
\hline $\begin{array}{l}\text { Pine } \\
\text { (Pinus sylvestris L.) }\end{array}$ & $\begin{array}{l}\text { Pine } \\
\text { (Pinus sylvestris L.) }\end{array}$ & $\begin{array}{l}\text { Pine } \\
\text { (Pinus sylvestris L.) }\end{array}$ \\
\hline $\begin{array}{l}\text { Spruce } \\
\text { (Picea abies L.) }\end{array}$ & $\begin{array}{l}\text { Spruce } \\
\text { (Picea abies L.) }\end{array}$ & $\begin{array}{l}\text { Spruce } \\
\text { (Picea abies L.) }\end{array}$ \\
\hline $\begin{array}{l}\text { Birch } \\
\text { (Betula pendula Roth) }\end{array}$ & $\begin{array}{l}\text { Birch } \\
\text { (Betula pendula Roth) }\end{array}$ & $\begin{array}{l}\text { Birch } \\
\text { (Betula pendula Roth) }\end{array}$ \\
\hline $\begin{array}{l}\text { Cowberry } \\
\text { (Vaccinium } \\
\text { vitis-idaea L.) }\end{array}$ & $\begin{array}{l}\text { Cowberry } \\
\text { (Vaccinium } \\
\text { vitis-idaea L.) }\end{array}$ & $\begin{array}{l}\text { Cowberry } \\
\text { (Vaccinium } \\
\text { vitis-idaea L.) }\end{array}$ \\
\hline $\begin{array}{l}\text { Blueberry } \\
\text { (Vaccinium } \\
\text { myrtillus L.) }\end{array}$ & $\begin{array}{l}\text { Blueberry } \\
\text { (Vaccinium } \\
\text { myrtillus L.) }\end{array}$ & $\begin{array}{l}\text { Blueberry } \\
\text { (Vaccinium } \\
\text { myrtillus L.) }\end{array}$ \\
\hline Green mosses & Green mosses & Green mosses \\
\hline Lichens & Lichens & Lichens \\
\hline & $\begin{array}{l}\text { Heather } \\
\text { (Calluna vulgaris L.) }\end{array}$ & $\begin{array}{l}\text { Juniper } \\
\text { (Juniperus } \\
\text { communis L.) }\end{array}$ \\
\hline & & $\begin{array}{l}\text { Melampyrum } \\
\text { (Melampyrum } \\
\text { pratense L.) }\end{array}$ \\
\hline
\end{tabular}


are linear over the concentration range recorded in this study with a correlation coefficient of 0.99 .

\section{Statistical analysis}

All analytical measurements were performed in triplicate. The results of the experiments are presented in the form of an average of the arithmetic means and their standard error. To establish the statistical relationships between the parameters, Student's t-test was used at a confidence level of $\mathrm{P}=95 \%$. A statistical analysis was performed in Python (version 2.7.12, 2016) in the SkiPy package (version $0.18 .1,2016$ ) using the Statistica 10 software package ("StatSoft", USA).

\section{Results and Discussion}

Vegetation is a good indicator of changes in environmental conditions due to terrain features. Lichens (Cladonia, Usnea) are widespread throughout the Arkhangelsk region, growing in both dry sandy and very wet conditions. Due to their long life, they are continuously subjected to stress over a long period of time and as a consequence have evolved protective measures. There- fore, these species are convenient models for studying the various modes of adaptation of vegetation to growing on these tectonic structures.

The reactions of the multilevel structural and functional organisation of plants to the influence of tectonics is mixed. The accumulation of heavy metals, the lack of moisture and the influence of geomagnetic fields provoke changes in the biochemical cycles of plant development, which are manifested both at the macro and micro structural levels. Visually there is an obvious retardation of growth, excessive branching and other morphological abnormalities, which may indicate irreversible changes in the plants due to a restructuring of their metabolism.

In tectonic fault zones there are multi-stemmed trees, the causes of which have not been fully elucidated. The indirect evidence of these abnormalities is that they were induced by the geological heterogeneities in the Earth's crust. The high frequency of "witches broom" in these zones is not due to infections but to mutations (Korovin et al. 2003). In forests in the Trans-Urals in areas with tectonic faults, birch trees are highly polymorphic (Mamaev 1973; Makhnev 1987). An example of this is Karelian birch, which results from abnormal cambial activity
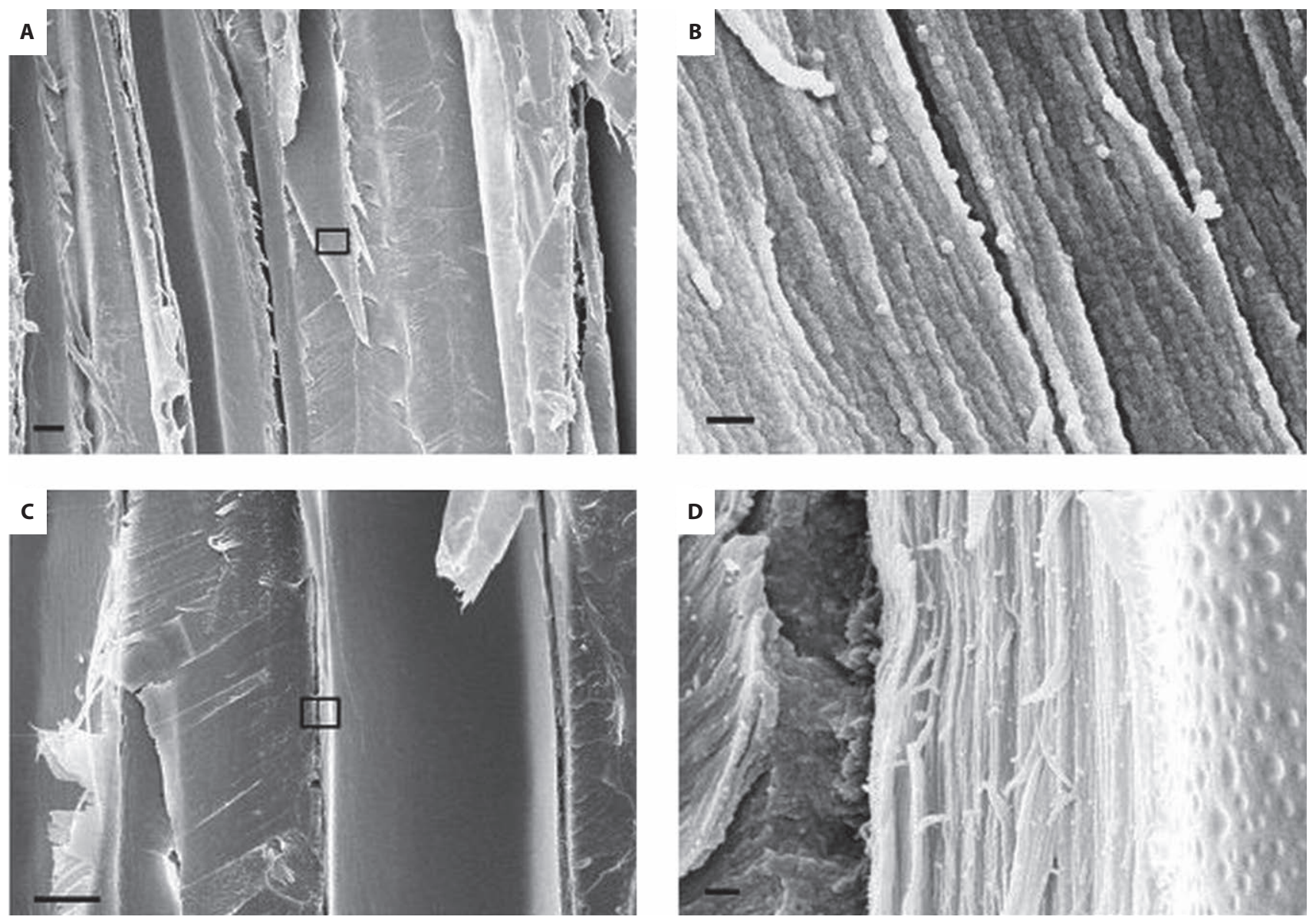

Fig. 2 Micrographs of chips from core samples; (a) cleavage of the cell wall showing the typical orientation of microfibrils in the $\mathrm{S}_{2}$ layer (control); (b) the area selected in Fig. 2a highly magnified; (c) cleavage of the cell wall with a fibre orientated parallel to the fibre in the microfibril in the $\mathrm{S}_{2}$ layer (centre of the node); (d) the area selected in Fig. 2c highly magnified. Bars: (a), (c) 10 microns; (b) $100 \mathrm{~nm}$; (d) $200 \mathrm{~nm}$. 
and a reduction in the distribution of photosynthates by the phloem to the xylem and increase in the distribution to the cortex. Structural and functional deviations from normal growth and development in plants may indicate an increase in cell growth and differentiation, phenol metabolism and respiration when under stress.

In transverse chips from the core samples, there is sometimes an atypical orientation of the cellulose relative to the fibre axis in microfibers in the $\mathrm{S}_{2}$ layer of the cell wall (Fig. 2).

The angle can be up to $0^{\circ}$ (this conclusion is not statistically significant).

Increasing the thickness of the cell wall reduces its permeability to toxic metabolic products and heavy metals, and protects the cellular components of the plants. Woody plants actively adapt to unfavourable environmental conditions by growing more slowly, as is clearly shown by the width of their annual rings, which are narrower in the centre of the TK than in the control area.

The soil in the different types of forest in the TK zone contains significantly more of the typical lithogenous macro- and microelements $\left(\mathrm{mg} \mathrm{g}^{-1}\right)$ : $\mathrm{Si}(4.8-36.5), \mathrm{Ca}$ (2.7-4.0), Al (3.4-4.9), Fe (2.2-4.3), Na (0.9-1.3), $\mathrm{Mg}$ (0.4-1.1), Mn (0.23-0.31), Ti (0.1-0.6), Cu (0.05-0.06) and $\mathrm{Zn}(0.04-0.07)$ than in the control areas: $\mathrm{Si}(1.8-26.1)$, $\mathrm{Al}(0.8-1.83), \mathrm{Ca}(0.7-1.57)$ and $\mathrm{Na}(0.7-1.0)$.

It is known that the elemental composition of plants is relatively stable. However, the geochemical environment and ecological conditions in the TK zone can result in lichens accumulating significantly more of certain elements. The mineral composition of the lichens is correlated with the mineral composition of the soil covering the TK. The content of macro- and microelements in the ash of lichens growing there is greater than in the control area, which indicates that their mineral composition reflects the geochemical features of the landscape. Lichens growing at the periphery and in the centre of the TK contained a number of typical lithogenic elements: $\mathrm{Si}>\mathrm{Al}>$ $\mathrm{Ca}>\mathrm{K}>\mathrm{Mg}>\mathrm{Fe}>\mathrm{Mn}>\mathrm{Cu}>\mathrm{Zn}$. The ash content of the lichen Cladonia stellaris growing in the centre of the TK is double (1.12-1.22\%) that of the control (0.56-0.58\%), and for the lichen Usnea subfloridana, it is 7 times higher in the centre of the TK $(6.82-6.99 \%)$ than in the control area $(0.97-1.09 \%)$. That is, lichens growing tectonic fault zones accumulate significant amounts of various metals. The ash content of the bark of tress growing in the centre of the TK (1.27-1.29\%) is double that of the control $(0.56-0.76 \%)$, which again reflects the lithochemical features of the sedimentary rocks in the upper part of the TK. The chemical elements in the soil are possibly taken up by the roots of the trees in which it accumulates in the wood and bark, and in lichens. In addition, the lower average monthly rainfall in summer at the centre of the TK affects the increase in the content of mobile forms of metals in the upper horizon of the soil $(0-20 \mathrm{~cm})$, which creates extremely unfavourable conditions for plant growth.

Lichens are an integral component of most plant communities. Their diversity and distribution are largely determined by the ecological conditions in a region. The high sensitivity of lichens to stress, and, accordingly, their high rate of biochemical reactions, are due to the fact that the metabolic equilibrium between the photobiont and the mycobiont is easily disturbed, as evidenced by the indices of biochemical reactions taking place in lichens (the content of ascorbic acid, phenolic compounds, lichen acids and so on) (Brovko et al. 2015; Brovko et al. 2016).

It is known that ascorbic acid (AA), due to its ability to easily donate electrons, is the leading non-enzymatic antioxidant (Chapin 1991). In the centre and at the periphery of the TK, the content of AA in lichens is higher (Fig. 3) than in the control area.

This activation of free radical oxidation is a nonspecific form of resistance shown by lichens when subjected to various stressors (Chapin 1991).

Phenolic compounds (PCs) is one of the most common classes of secondary metabolites, the formation of which is characteristic of virtually all plant cells. They take part in a wide variety of physiological processes, such as photosynthesis, respiration, formation of cell walls and resistance of plants to the action of heavy metals (Brovko et al. 2017). In the literature, there are more than 1000 PCs characteristic of lichens, the so-called "li-

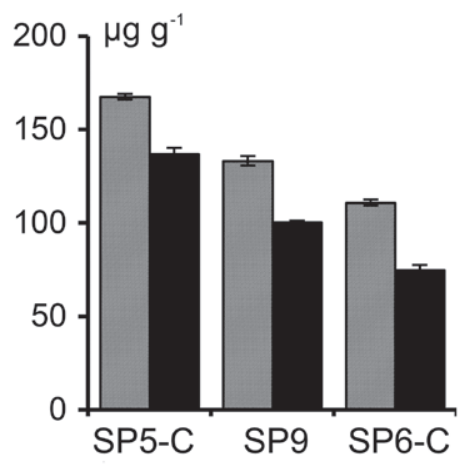

spring

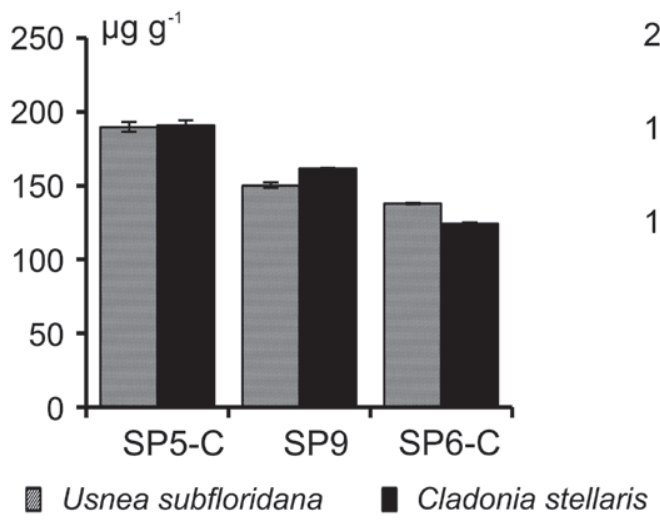

summer

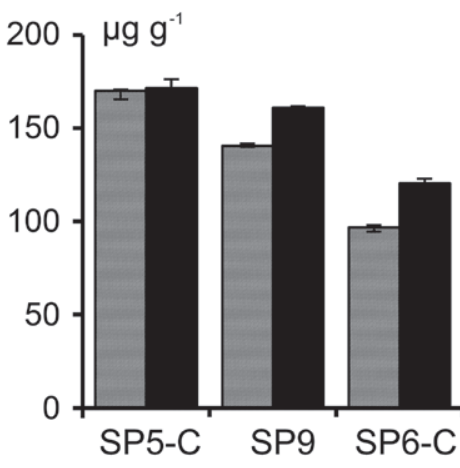

autumn

Fig. 3 Ascorbic acid contents of the lichens Usnea subfloridana and Cladonia stellaris growing at different locations on the TK. 


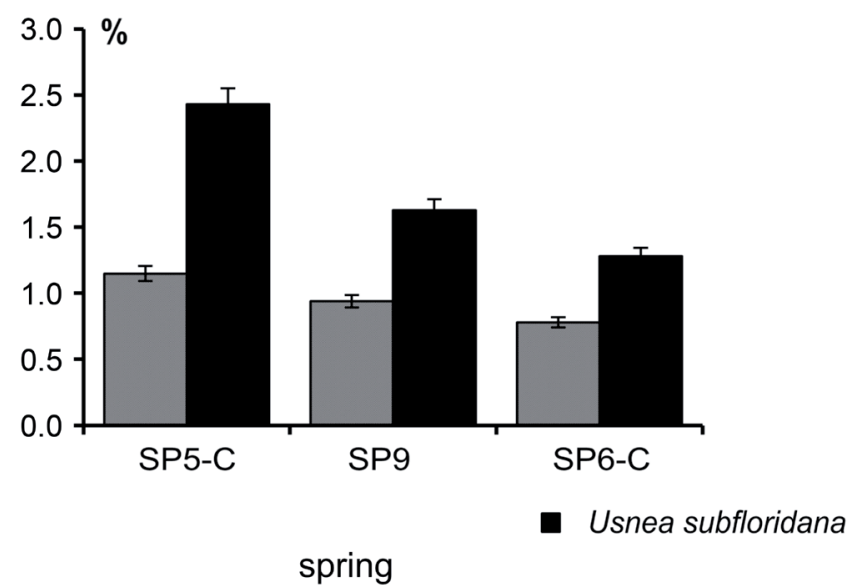

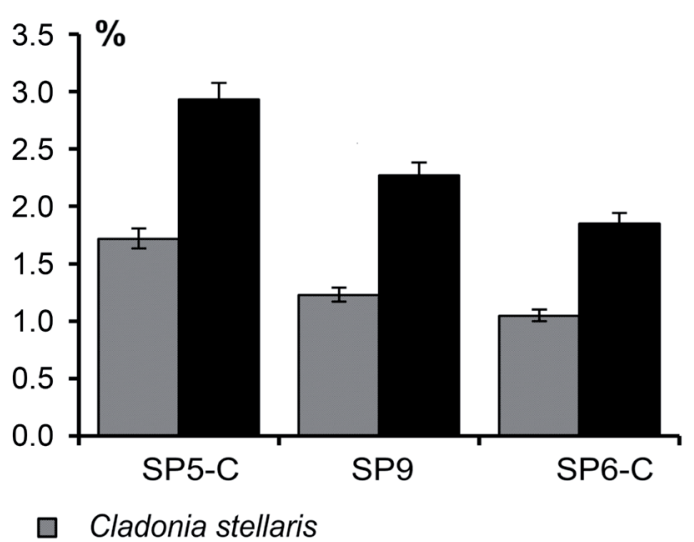

summer

Fig. 4 Usnic acid content of lichens, \% of a.d.w.

chen substances" (Molnar and Farkas 2010), of which the most commonly found is tallow and the well-known usnic acid (UA) (Brovko et al. 2017).

The changes in the content of acids in lichens growing in different environments is of particular interest. Our studies show that the content of UA, a typical secondary metabolite of lichens (Brovko et al. 2017), in Usnea subfloridana and Cladonia stellaris varied depending where they grew in the TK zone (Fig. 4).

There are seasonal fluctuations in the amount of UA, which indicate that lichen acids actively participate in metabolism and sometimes accumulate in the thallus in significant amounts. An important function of these acids is regulatory. An increase in their content promotes photosynthesis of algal cells - lichen symbionts, which dramatically increases the amount of organic matter needed for the symbiotic fungus. The increase in UA at the centre of the TK by 1.5-2 times in the lichen Usnea subfloridana and 1.5 times in the lichen Cladonia stellaris compared to the control, indicates the high adaptive capacity of lichen symbionts to combat the adverse environmental factors that these lichens are exposed to.

An important role of lichen acids is the allelopathic interaction with other components of phytocenoses, in particular, tree-destroying fungi. Analysis of samples of wood to determine the number of trees infected with the root fungus (Heterobasidion annosum Fr.) in the centre of the TK revealed that less than half of the spruce and none of the pines were infected compared with the control. Apparently, lichens growing on trees make them more resistant to wood-destroying fungi (Henningsson and Lundstrom 1970), which is due to the high fungicidal effect of lichen acids.

\section{Conclusion}

The results of this research show that the adverse conditions at TK zones induce in plants biochemical and biophysical reactions that enable them to survive in these areas. At these sites, the structure of the cell walls of woody plants differ in a way that reduces their permeability to toxic metabolic products and heavy metals. The growth of some of the trees at the centre of the TK was abnormal because the conditions experienced there adversely affected the activity of their cambium. The synergism between trees and lichens provides ascorbic and lichen acids that inhibit the oxidation of free radicals. Thus, there are two ways of adapting to environmental stress. One is associated with a change in the structure of the cell walls of plants (barrier) and the other with the activation of systems that detoxify reactive oxygen species and free organic radicals.

\section{Acknowledgements}

This research was funded by the FASO of Russia under project agreement No. AAAA-A18-118012390305-7 "Study of inter-geospheric processes in areas of tectonic structures and nodes of their intersections in the geological conditions of ancient platforms on the example of the Arkhangelsk region", project agreement No. AAAA-A18-118012390231-9 "Physic-chemical, genetic and morphological bases of the plant objects adaptation under the conditions of the changing climate of high latitudes" and Russian Foundation for Fundamental Research, Project No. 18-05-60024. We used the equipment of CCU SE "Arctic" [Northern (Arctic) Federal University) and of CCU SE CT RF-Arctic (N. Laverov Federal Center for Integrated Arctic Research).

\section{REFERENCES}

Alscher RG, Donahue JL, Cramer CL (1997) Reactive Oxygen Species and Antioxidant: Relationships in Green Cells. Plant Physiol 100: 224-233, https://doi.org/10.1111/j.1399-3054.199 tb04778.x

Aroca R, Irigoyen JJ, Sanchez-Diaz M (2001) Photosynthetic characteristics and protective mechanisms against oxidative stress during chilling and subsequent recovery in two maize varieties differing in chilling sensitivity. Plant Sci 161: 719-726, https:// doi.org/10.1016/S0168-9452 (01)00460-5. 
Atlas of the Arkhangelsk region (1976) General administration of geodesy and cartography, Moscow, USSR.

Bense VF, Gleeson T, Loveless SE, Bour O, Scibek J (2013) Fault zone hydrogeology. Earth-Scie Rev 127: 171-192, https://doi .org/10.1016/j.earscirev.2013.09.008.

Beschel RE (1957) A project to use Lichens as indicators of climate and time. Arctic Alpine Res 10: 200-215.

Brovko OS, Palamarchuk IA, Boitsova TA, Bogolitsyn KG, Valchuk NA, Ivakhnov AD (2015) Comparative analysis of traditional and modern extraction methods of usnic acid from raw lichen material. Fund Res 11: 659-663, https://doi.org/10.17513 /fr.39481.

Brovko OS, Palamarchuk IA, Sloboda AA, Boytsova TA, Gagushkina AA, Valchuk NA, (2016) The influence of stress factors on the chemical composition of lichens genus Cladonia of Euro-Arctic region. Adv Nat Sci: 20-24, https://doi.org/10.17513 /use.36072.

Brovko OS, Ivakhnov AD, Palamarchuk IA, Boitsova TA (2017) Supercritical Fluid Extraction of Usnic Acid from Lichen of Cladonia Genus. Russ J Phys Chem B+ 11: 1306-1311.

Caine JS, Evans JP, Forster CB (1996) Fault zone architecture and permeability structure. Geology 24: 1025-1028, https://doi.org /10.1130/0091-7613(1996)024<1025:FZAAPS>2.3.CO;2.

Caine JS, Forster CB (1999) Fault zone architecture and fluid flow: Insights from field data and numerical modeling. In: Haneberg WC, Mozley PS, Moore JC, Goodwin LB (eds) Faults and subsurface fluid flow in the shallow crust. American Geophysical Union, Washington DC, USA, pp. 101-127.

Chapin FS (1991) Integrated responses of plants to stress. A centralized system of physiological responses. BioScience 41: 29-37, https://doi.org/10.2307/1311538.

Chirkova TV (2002) Physiological basis of plant tolerance. Izdatelstvo Sankt-Peterburgskogo Universiteta, Saint Petersburg, Russian Federation.

Evans JP, Forster CB, Goddard JV (1997) Permeability of fault-related rocks, and implications for hydraulic structure of fault zones. J Struct Geol 19: 1393-1404, https://doi.org/10.1016 /S0191-8141(97)00057-6.

Gofarov MYu, Kutinov YuG, Bolotov IN (2006) Landscapes of the Belomorsko-Kuloyskoe plateau: tectonics, bedrock, topography and vegetation. Ural Branch of RAS, Ekaterinburg, Russian Federation.

Golubkova NS, Savich VP, Trass HH (1978) The determinant of lichens of the USSR. Vol. 5. Cladoniaceae-Acarosporaceae. Nauka, Leningrad, USSR.

Henningsson B, Lundstrom H (1970) The influence of lichens, lichen extracts and usnic acid on wood destroying fungi. Mater Organismen 5: 19-31.

Korovin VV, Novitskaya LL, Kurnosov GA (2003) Structural anomalies of the stem of woody plants. Publishing House of the Moscow State University of Forest, Moscow, Russian Federation.

Kutinov YuG, Chistova ZB, Belyaev VV, Burlakov PS (2009) The Influence of tectonic disturbances (degassing, induced currents, variations) of the North Russian plate on the environment (on the example of the Arkhangelsk region) Vestnik KRAUNZ Earth Sci 2: 77-89.

Kutinov YuG, Chistova ZB (2012) Complex model of geospheres interaction processes in the tectonic nodes at the North Russian plate. Electronic scientific publication Almanac Space and Time 1: 9 [online 22 June 2018], http://www.j-spacetime.com /actual\%20content/t1v1/1109.php.

Magomedova MA (1996) Lichens as a component of northern ecosystems and the monitoring object. Problems of ecological monitoring and ecosystem modelling. XVI. Gidrometeoizdat, Sankt-Petersburg Russian Federation.

Makhnev AK (1987) Intraspecies variation and population structure of birches of sections Albae and Nanae. Nauka, Moscow, USSR.

Mamaev SA (1973) Forms of intraspecific variation of woody plants. Nauka, Moscow, USSR.

Markovskaya EF, Sergienko LA, Shklyarevich GA, Sonina AV, Starodubtseva AA, Smol'kova OV (2010) Natural complex of the White Sea coasts. KarRC of RAS Publ., Petrozavodsk, Russian Federation.

Meloni DA, Oliva MA, Martinez CA, Cambraia J (2003) Photosynthesis and Activity of Superoxide Dismutase, Peroxidase and Glutathione Reductase in Cotton under Salt Stress. Environ Exp Bot 49: 69-76, https://doi.org/10.1016/S0098-8472 (02)00058-8.

Molnar K, Farkas E (2010) Current results on biological activities of lichen secondary metabolites: a review. Z Naturforsch 65: 157-173.

Polesskaya OG, Kashirina EI, Alekhina ND (2004) Changes in the activity of antioxidant enzymes in leaves and roots of wheat depending on the form and dose of nitrogen in the medium. Plant Physiol 51: 686-691.

Prasad KVSK, Saradhi PP, Sharmila P (1999) Concerted Action of Antioxidant Enzymes and Curtailed Growth under Zinc Toxicity in Brassica juncea. Environ Exp Bot 42: 1-10, https://doi .org/10.1016/S0098-8472(99)00013-1.

Rawling GC, Goodwin LB, Wilson JL (2001) Internal architecture, permeability structure, and hydrologic significance of contrasting fault-zone types. Geology 29: 43-46.

Rinn F (2007) TSAP - Win TM Professional. Zeitreihenanalyse und Präsentationfür Dendrochronologie und verwandte Anwendungen. Benutzerhandbuch RINNTECH, Heidelberg.

Rydzak J (1968) Lichens as indicators of the ecological conditions of the habitat. Annales Universitatis Mariae Curie-Sklodowska 23: 131-164.

Voskresenskaya OL (2006) Great Workshop on bioecology. Part 1. Textbook. Mari state University, Yoshkar-Ola, Russian Federation.

Zhang J, Kirkham MB (1994) Drought-Stress Induced Changes in Activities of Superoxide Dismutase, Catalase, and Peroxidase in Wheat Species. Plant Cell Physiol 35: 785-791, https://doi .org/10.1093/oxfordjournals.pcp.a078658. 